\title{
Penerapan Model Inkuiri Untuk Meningkatkan Aktivitas dan Pemahaman Konsep Siswa
}

\author{
Titin, Laili Fitri Yeni, Siti Fauziah \\ Pendidikan Biologi. FKIP. Universitas Tanjungpura
}

\begin{abstract}
This purpose of this research is to find out the implementation of inquiry model to improve the students' activity and comprehension of concept on the material about food digestion system to the eight year students (class VIII) of SMP Negeri 1 Sukadana. The method used in this research is experimental. The form of this research is quasy experimental by using one-short case study design. The population of this research is all the students of class VIII of SMP Negeri 1 Sukadana in academic year 2008/2009. The sample of this research consists of one class that is class VIII A. The tool of data collecting forms essay test that consists 6 items. The essay test has been validated by 2 validators and it had reliability 0,47 or categorized sufficient. Based on the result of data analysis, the students' comprehension of concept on the material is $64,53 \%$ and includes good category. Meanwhile, the students' activity percentage is $85,15 \%$ and includes active category. Therefore, it can be concluded that the implementation of inquiry model can improve the students' activity and comprehension of concept on the material about food digestion system.
\end{abstract}

Keyword : inquiry model, students' activity, students' comprehension of concept, food digestion system.

\section{Pendahuluan}

Biologi merupakan salah satu bagian dari ilmu pengetahuan alam (IPA). Pembelajaran biologi tidak hanya memperhatikan produknya saja tetapi juga prosesnya. Proses pembelajaran siswa tidak dapat hanya di lakukan dengan mentransfer ilmu begitu saja, tetapi pembelajaran harus lebih menekankan pada keterampilan siswa. Hal ini sesuai dengan pendapat Depdiknas (2006) yang menyatakan bahwa pendidikan tidak sekedar untuk mengetahui, tetapi lebih jauh untuk trampil berbuat dan mengerjakan sesuatu.
Proses pembelajaran IPA menekankan pada pemberian pengalaman langsung untuk mengembangkan kompetensi agar siswa menjelajahi dan memahami alam sekitar secara ilmiah. Dalam menjelajahi dan memahami alam sekitar secara ilmiah tersebut, siswa perlu dibantu untuk mengembangkan sejumlah keterampilan proses. Keterampilan-keterampilan proses ini meliputi keterampilan mengamati dengan seluruh indera, mengajukan hipotesis, menggunakan alat dan bahan secara benar dengan selalu mempertimbangkan keselamatan kerja. mengajukan pertanyaan, 
menggolongkan, menafsirkan data dan mengkomunikasikan hasil temuan secara beragam, menggali dan memilah informasi faktual yang relevan untuk menguji gagasangagasan atau memecahkan masalah sehari-hari (Depdiknas, 2003). Agar para siswa dapat mengembangkan berbagai keterampilan proses tersebut, maka pada pembelajaran IPA khususnya biologi, guru harus dapat menyediakan kegiatan yang dapat memberikan kesempatan kepada siswa untuk memunculkan keterampilan proses. Keterampilan proses harus didukung dengan berkembangnya rasa ingin tahu. kemauan bekerja sama. dan keterampilan berfikir kritis.

Model inkuiri menurut Gulo (2002) berarti suatu rangkaian kegiatan belajar yang melibatkan secara maksimal seluruh kemampuan siswa untuk mencari dan menyelidiki secara sistematis, kritis, logis, analitis, sehingga mereka dapat merumuskan sendiri penemuannya dengan penuh percaya diri. Di dalam inkuiri, siswa dimotivasi untuk terlibat langsung dan berperan aktif secara fisik dan mental dalam kegiatan pembelajaran lingkungan kelas, dimana siswa aktif terlibat serta guru berperan sebagai fasilitator pembelajaran sangat membantu dalam mencapai tujuan belajar. Model inkuiri dapat di lakukan secara perorangan, kelompok ataupun seluruh kelas. Baik dilakukan di dalam kelas maupun luar kelas (lingkungan laboratorium) hal ini ditegaskan oleh (Anonim, tanpa tahun).

Dalam pembelajaran IPA, pembelajaran melalui model ini akan membawa dampak besar bagi perkembangan mental positif siswa, sebab melalui model ini siswa dapat berfikir secara kritis dan analitis. untuk mencari dan menemukan sendiri jawaban dari suatu masalah yang ditanyakan.

Diperoleh informasi bahwa kegiatan pembelajaran di kelas masih didominasi oleh guru dan metode sang paling sering di gunakan oleh guru yaitu metode ceramah dan penugasan. Terlihat jelas interaksi antara guru dengan siswa sangat sedikit atau minim. Dari jumlah seluruh siswa yakni 46 orang hanya $40 \%$ siswa yang mendengarkan penjelasan guru, dan aktif dalam mengikuti pembelajaran. Sedangkan siswa yang lain terlihat pasif atau melakukan hal-hal yang tidak positif seperti berbicara dengan sesama teman sebangku atau mengerjakan tugas lain yang tidak berkaitan dengan pelajaran biologi. Kondisi ini pada akhirnya mengakibatkan kurangnya pemahaman siswa dalam memahami materi pelajaran yang disampaikan.

Sejalan dengan yang ditegaskan oleh (Anonim, tanpa tahun) bahwa dalam pelaksanaan pengajaran yang masih menggunakan metode ceramah dan penugasan dapat mengakibatkan kurangnya motivasi dan keterlibatan siswa dalam pembelajaran. Sehingga kurangnya pemahaman siswa dalam memahami materi pelajaran yang disampaikan. Dari latar belakang di atas, penulis tertarik untuk meneliti dan memilih model inkuiri karena dalam tahap pembelajarannya dapat memunculkan keterampilan proses siswa serta dapat membantu siswa dalam mengkonstruksi pemahaman mereka. Dengan demikian 
diharapkan dapat meningkatkan aktivitas dan pemahaman konsep serta penerapannya dalam kehidupan yang sesuai dengan tuntutan standar kompetensi bidang biologi tingkat SMP.

Materi sistem pencernaan makanan dipilih oleh penulis, karena berdasarkan informasi dari guru, masih banyak siswa yang kesulitan dalam memahami materi ini, terutama membedakan antara saluran pencernaan dan kelenjar pencernaan. Hal ini dapat dilihat dari nilai ratarata ulangan materi sistem pencernaan masih tergolong rendah yaitu 40,7 dari KKM sebesar 50 . Materi biologi pada pokok bahasan sistem pencernaan pada materi ini merupakan salah satu materi yang dapat diajarkan dengan model inkuiri.

Indikator dan tujuan pembelajaran pada materi sistem pencernaan makanan ini adalah agar siswa mampu membedakan antara saluran pencernaan dan kelenjar pencernaan, membandingkan pencernaan mekanik dan kimiawi, dan mendeskripsikan jenis makanan berdasarkan kandungan zat yang ada di dalamnya. Diharapkan dengan digunakannya model inkuiri dapat meningkatkan aktivitas siswa sehingga dapat meningkatkan hasil belajar siswa yang merupakan dampak dari pengalaman belajar secara langsung dan berpusat pada diri mereka sendiri sebagai siswa.

Sesuai dengan apa yang telah disebutkan pada butir permasalahan, penelitian ini dilakukan dengan tujuan untuk mengetahui bagaimana penerapan model inkuiri dapat meningkatkan aktivitas dan pemahaman konsep siswa pada pokok bahasan sistem pencernaan makanan di kelas VIII SMP Negeri 1 Sukadana. Hasil penelitian ini dapat bermanfaat bagi guru sebagai salah satu model pembeläjaran yang dapat digunakan dalam mengajarkan biologi khususnya pada materi sistem pencernaan makanan. Bagi siswa, model pembelajaran ini dapat mengembangkan kemampuan berfikir siswa agar lebih tanggap. cermat dan nalar, meningkatkan aktivitas siswa, serta dapat memberikan pengalaman baru dan pembelajaran biologi. Bagi sekolah hasil penelitian ini dapat meningkatkan prestasi sekolah melalui peningkatan aktivitas siswa. Bagi peneliti dapat memperoleh pengalaman langsung dalam mengajarkan biologi dengan model inkuiri.

\section{Tinjauan Pustaka}

Biologi merupakan ilmu untuk meningkatkan pengetahuan, keterampilan, sikap, dan nilai. Biologi berkaitan dengan cara mencari tahu dan memahami alam secara sistematis. Biologi bukan hanya penguasaan kumpulan pengetahuan yang berupa faktafakta, konsep-konsep, prinsip prinsip saja, tetapi juga merupakan suatu proses penemuan. Model inkuiri adalah cara belajar mengajar untuk mengembangkan keterampilan memiliki dan memecahkan masalah dengan menggunakan pola berfikir kritis.

$$
\text { Menurut Sanjaya (2008) }
$$
inkuiri adalah rangkaian kegiatan pembelajaran yang menekankan pada proses berfikir secara kritis dan analitis untuk mencari dan menemukan sendiri jawaban yang 
sudah pasti dari suatu masalah yang dipertanyakan.

Menurut Putrayasa (dalam Admin, 2009) model inkuiri mempunyai ciriciri sebagai berikut :

1. Menggunakan keterampilan proses

2. Jawaban yang dicari siswa tidak diketahui terlebih dahulu

3. Siswa berhasrat untuk menemukan pemecahan masalah

4. Suatu masalah ditemukan dengan pemecahan siswa sendiri

5. Hipotesis dirumuskan oleh siswa untuk membimbing percobaan atau eksperimen.

6. Para siswa mengusulkan caracara pengumpulan data dengan mengumpulkan data, mengadakan pengamatan, membaca/menggunakan sumber lain.

7. Siswa melakukan penelitian secara individu/kelompok untuk mengumpulkan data yang diperlukan untuk menguji hipotesis tersebut.

8. Siswa mengolah data sehingga mereka sampai pada kesimpulan.

Kendatipun model ini berpusat pada kegiatan peserta didik, namun guru tetap memegang peranan penting sebagai pembuat desain pengalaman belajar. Guru berkewajiban menggiring peserta didik untuk melakukan kegiatan. Kadangkala guru perlu memberikan penjelasan. memberikan pertanyaan. memberikan komentar, dan saran kepada peserta didik. Guru berkewajiban memberikan kemudahan belajar melalui penciptaan belajar yang kondusif, dengan menggunakan fasilitas media dan materi pembelajaran yang bervariasi.

Inkuiri pada dasarnya adalah menyadari apa yang telah dialami, karena itu inkuiri menuntut peserta didik berfikir. Model ini melibatkan mereka dalam kegiatan intelektual. Model ini menuntut peserta didik memproses pengalaman belajar menjadi sesuatu yang bermakna dalam kehidupan nyata. Dengan demikian, melalui model ini dibiasakan untuk produktif, analitis dan kritis.

Menurut Roestiyah (2001) model inkuiri memberikan sesuatu cara yang baik dalam mengajar sains untuk semua siswa. Beberapa keunggulan mengajar sains melalui inkuiri yaitu :

1. Membantu dalam menggunakan ingatan dan transfer pada situasi proses belajar yang baru.

2. Mendorong siswa untuk berfikir intuitif dan merumuskan hipotesisnya sendiri.

3. Memberikan kepuasan yang bersifat intrinsik.

4. Situasi proses belajar menjadi lebih merangsang.

5. Dapat mengembangkan bakat atau kecakapan individu.

6. Memberikan kebebasan siswa untuk belajar sendiri.

7. Siswa dapat menghindari caracara belajar tradisional.

8. Dapat memberikan waktu pada siswa secukupnya sehingga mereka dapat mengasimilasi dan mengakomodasi informasi

Aktivitas siswa selama proses belajar mengajar merupakan salah satu indikator adanya keinginan siswa 
untuk belajar. Aktivitas siswa merupakan kegiatan atau perilaku yang terjadi selama proses belajar mengajar. Kegiatan-kegiatan yang dimaksud adalah kegiatan yang mengarah pada proses belajar seperti bertanya. mengajukan pendapat, mengerjakan tugas-tugas, dapat menjawab pertanyaan guru dan bisa bekerja sama dengan siswa lain, serta tanggung jawab terhadap tugas yang diberikan (Yasa, 2008).

Untuk dapat memproses dan mengolah perolehan belajarnya secara efektif. siswa dituntut untuk untuk aktif secara fisik, intelektual, dan emosional. Implikasi prinsip keaktifan bagi siswa berwujud perilaku-perilaku seperti mencari sumber informasi yang dibutuhkan, menganalisis hasil percobaan, ingin tahu dari hasil percobaan, membuat karya tulis, dan perilaku sejenis lainnya.

Menurut Driver (dalam Suzana, 2003) pemahaman adalah kemampuan untuk menjelaskan suatu situasi atau suatu tindakan.

Tingkat pemahaman konsep yang telah dimiliki oleh siswa tergantung kepada pencapaiannya terhadap penilaian hasil pembelajaran. Penilaian ini dilakukan untuk mengetahui konsep mana sajakah yang sudah dikuasai oleh siswa. Perolehan tingkat pemahaman konsep siswa dapat dilihat dibuat sebelum pengajaran.

Menurut Bloom (dalam Gulo, 2002) taksonomi tujuan pengajaran dalam kawasan kognitif terdiri atas enam tingkatan yang susunanya sebagai berikut :
1. Pengetahuan (C1) yaitu kemampuan untuk mengenal atau mengingat kembali sesuatu objek, ide, prosedur, prinsif, atau teori yang pernah ditemukan dalam pengalaman tanpa memanipulasikannya dalam bentuk atau simbol lain.

2. Pemahaman (C2) yaitu kegiatan mental intelektual mengorganisasikan materi yang telah diketahui.

3. Penerapan (C3) yaitu kemampuan untuk menggunakan konsep, prinsip, prosedur atau teori tertentu pada situasi tertentu.

4. Analisis (C4) yaitu kemampuan untuk menguraikan bahan-bahan pelajaran ke dalam unsurunsurnya, kemudian menghubungkan bagian dengan cara disusun dan diorganisasikan.

5. Sintesis (C5) yaitu kemampuan untuk mengorganisasikan semua unsur sehingga membentuk satu keseluruhan secara utuh.

6. Evaluasi (C6) yaitu kemampuan untuk mengambil keputusan, memberi penilaian berdasarkan

kriteria-kriteria tertentu baik kualitatif maupun kuantitatif. Materi sistem pencernaan makanan dalam penelitian ini mencakup organ-organ saluran pencernaan dan kelenjar pencernaan, jenis dan fungsi makanan.

\section{Metode Penelitian}

Penelitian ini merupakan penelitian eksperimen. Penelitian penelitian eksperimen adalah suatu penelitian yang berusaha mencari pengaruh variabel tertentu terhadap variabel yang lain dalam kondisi 
yang terkontrol secara ketat (Sugiyono, 1997). Berdasarkan jenis penelitiannya maka, rancangan yang di gunakan adalah : One-shot case study (Sugiyono. 1997) dengan pola sebagai berikut :

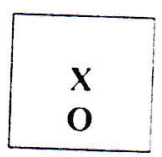

Keterangan :

$\mathrm{X}=$ Penerapan model inkuiri pada sistem pencernaan makanan.

$\mathrm{O}=$ Pengukuran yang terdiri dari atas aktivitas dan pemahaman konsep oleh siswa

Subyek dalam penelitian ini adalah siswa kelas VIII SMP Negeri 1 Sukadana dengan jumlah 45 orang. Instrumen yang digunakan dalam penelitian ini berupa lembar observasi aktivitas siswa yang digunakan untuk melihat aktivitas siswa dalam pembelajaran dan tes pemahaman yang digunakan mengetahui pemahaman konsep siswa. Observasi aktivitas dilakukan oleh 2 orang guru. Validasi instrumen yang digunakan adalah validasi isi. Sebuah tes dikatakan memiliki validasi isi apabila mengukur tujuan khusus tertentu sesuai dengan isi pelajaran yang diberikan (Arikunto, 2002).
Reliabilitas tes ditentukan dengan mengujicobakan tes tersebut. Reliabilitas menunjukkan pada suatu pengertian bahwa suatu instrumen cukup dapat dipercaya untuk digunakan sebagai alat pengumpul data karena instrumen tersebut sudah baik. Reliabilitas tes secara keseluruhan dihitung dengan menggunakan rumus alpha yaitu R11. Dari hasil coba tes, diperoleh perhitungan reliabilitas dengan nilai $r$ $=0.47$ yang berarti cukup reliabel.

Adapun prosedur dalam penelitian ini adalah sebagai berikut yaitu membuat instrumen yaitu lembar observasi dan tes pemahaman, uji coba tes, perbaikan instrumen, pelaksanaan penelitian, pengumpulan data hasil penelitian, dan analisis data yang terkumpul untuk menjawab pertanyaan penelitian.

Data dianalisis secara kuantitatif dengan langkah sebagai berikut; menurut Alhaddad (2002) data yang diperoleh dari hasil observasi aktivitas dipresentasekan dengan menggunakan rumus :

$\mathrm{Ti}=\frac{X i}{N} \times 100 \% \quad$ kemudian hasil persentase yang didapat dikategorikan kedalam kategori aktivitas.

Tabel 1. Kategori Aktivitas

\begin{tabular}{|c|c|}
\hline Presentase & Kategori \\
\hline $86-100$ & Sangat aktif \\
\hline $76-85$ & Aktif \\
\hline $60-75$ & Cukup \\
\hline $55-59$ & Pasif \\
\hline$\leq 54$ & Pasif sekali \\
\hline
\end{tabular}


Data yang diperoleh dari hasil tes pemahaman diolah dengan langkahlangkah sebagai berikut; NILAI $=\frac{\text { jumlah skor yang diperoleh }}{\text { jumlah skor maksimum }} \times 100 \%$
Untuk mengetahui tingkat pemahaman konsep siswa digunakan kriteria skor sebagai berikut :

Tabel 2. Kategori pemahaman

\begin{tabular}{|l|l|}
\hline Persentase & Kategori \\
\hline $81-100$ & Sangat baik \\
\hline $61-80$ & Baik \\
\hline $41-60$ & Cukup \\
\hline $21-40$ & Kurang \\
\hline$<20$ & Sangat kurang \\
\hline
\end{tabular}

(Riduwan, 2002)

\section{Hasil dan Pembahasan}

Penelitian dilaksanakan di kelas VIII A SMP Negeri 1 Sukadana dengan jumlah siswa 46 orang dan berlangsung dalam dua kali pertemuan. Model yang digunakan pada penelitian ini adalah model inkuiri (model yang dapat membuat siswa berfikir secara kritis dan analisis untuk membedakan antara saluran pencernaan dan kelenjar pencernaan). Pada pertemuan $I$ penyajian informasi dengan menonton tayangan VCD sistem pencernaan makanan. Sedangkan pada pertemuan II penyajian informasi dengan melakukan uji makanan.

Tabel 3. Persentase Rata-rata Aktivitas Siswa Selama KBM

\begin{tabular}{|c|c|c|c|c|c|}
\hline \multirow{2}{*}{ No } & \multirow{2}{*}{ Kategori pengamatan } & \multicolumn{2}{|c|}{ Persentase aktivitas siswa } & \multirow{2}{*}{$\begin{array}{l}\text { Rata- } \\
\text { rata }\end{array}$} & \multirow{2}{*}{$\begin{array}{l}\text { Kategori } \\
\text { keaktifan }\end{array}$} \\
\hline & & Pertemuan I & Pertemuan II & & \\
\hline 1 & $\begin{array}{l}\text { Bersikap relevan } \\
\text { dengan KBM }\end{array}$ & 87,21 & 86.6 & 87 & $\begin{array}{c}\text { Sangat } \\
\text { aktif }\end{array}$ \\
\hline 2 & $\begin{array}{l}\text { Memperhatikan dan } \\
\text { menyimak }\end{array}$ & 86,95 & 87,49 & 87,22 & $\begin{array}{c}\text { Sangat } \\
\text { aktif }\end{array}$ \\
\hline 3 & Membaca & 80,54 & 73,47 & 77 & Aktif \\
\hline 4 & Menulis & 84,04 & 86,21 & 85,12 & Aktif \\
\hline 5 & $\begin{array}{l}\text { Berdiskusi dengan } \\
\text { teman sekelompok }\end{array}$ & 84,77 & 86,95 & 85,86 & Aktif \\
\hline 6 & $\begin{array}{l}\text { Mempresentasikan } \\
\text { hasil karya }\end{array}$ & 97,82 & 89,12 & 93,47 & $\begin{array}{c}\text { Sangat } \\
\text { aktif }\end{array}$ \\
\hline \multirow[t]{3}{*}{7} & Memberi tanggapan & 77,17 & 83,69 & 80,43 & Aktif \\
\hline & Total & 598,5 & 593,73 & 596,1 & \\
\hline & Rata-rata & 85,5 & 84.81 & 85,15 & Aktif \\
\hline
\end{tabular}


Secara keseluruhan rata-rata persentase aktivitas siswa selama KBM adalah 85,15\%, dengan kategori aktif. Artinya siswa bertingkah laku aktif dengan mengikuti pelajaran dengan serius, memperhatikan penjelasan guru dan bertanya jika belum mengerti dengan penjelasan guru serta mengerjakan dengan baik LKS yang diberikan oleh guru. Dari data di atas, aktivitas siswa tertinggi yaitu mempresentasikan hasil karya sebesar 93,47\% dengan kategori sangat aktif. Artinya siswa telah mampu mempresentasikan hasil karya secara aktif. Tingginya persentase aktivitas siswa tersebut menunjukkan bahwa pembelajaran dengan menerapkan model inkuiri pada materi sistem pencernaan makanan merupakan model pembelajaran yang menekankan kepada aktivitas belajar siswa dalam menemukan sendiri jawaban dari pertanyaan yang diberikan, sehingga dapat merangsang siswa untuk terlibat aktif dalam belajar. Hal ini sejalan dengan pendapat Roestivah (2001) bahwa model inkuiri dapat menimbulkan situasi proses belajar menjadi lebih merangsang siswa untuk belajar.

Tabel 4. Persentase Rata-rata Pemahaman Konsep Siswa Selama KBM

\begin{tabular}{|c|c|c|c|c|c|}
\hline \multirow{2}{*}{$\begin{array}{l}\text { No } \\
\text { soal }\end{array}$} & \multirow{2}{*}{ Aspek } & \multirow{2}{*}{ Konsep } & \multicolumn{2}{|c|}{$\begin{array}{c}\text { Tes } \\
\text { pemahaman }\end{array}$} & \multirow{2}{*}{ Kategori } \\
\hline & & & $\begin{array}{l}\text { Skor } \\
\text { total }\end{array}$ & $\%$ & \\
\hline 1 & $\mathrm{C} 2$ & $\begin{array}{l}\text { Menyebutkan nama kelenjar } \\
\text { yang menghasilkan saliva dan } \\
\text { fungsinya }\end{array}$ & 40 & 48,5 & Cukup \\
\hline 2 & $\mathrm{C} 2$ & $\begin{array}{l}\text { Menyebutkan nama uji makanan } \\
\text { yang dilakukan }\end{array}$ & 73 & 89 & $\begin{array}{l}\text { Sangat } \\
\text { baik }\end{array}$ \\
\hline 3 & $\mathrm{C} 2$ & $\begin{array}{l}\text { Menyebutkan zat yang } \\
\text { terkandung dalam nasi,telur,susu } \\
\text { serta fungsinya }\end{array}$ & 175 & 71 & Baik \\
\hline 4 & $\mathrm{C} 2$ & $\begin{array}{l}\text { Menyebutkan tiga bagian dari } \\
\text { usus halus }\end{array}$ & 119 & 96,6 & $\begin{array}{c}\text { Sangat } \\
\text { baik }\end{array}$ \\
\hline 5 & $\mathrm{C} 2$ & $\begin{array}{l}\text { Menjelaskan cara-cara } \\
\text { pengujian lemak }\end{array}$ & 78 & 63,5 & Baik \\
\hline 6 & $\mathrm{C} 2$ & $\begin{array}{l}\text { Menyebutkan saluran } \\
\text { pencernaan dan kelenjar } \\
\text { pencernaan }\end{array}$ & 67 & 18,8 & $\begin{array}{l}\text { Sangat } \\
\text { kurang }\end{array}$ \\
\hline & & Rata-rata & 92 & 64,53 & Baik \\
\hline
\end{tabular}

Berdasarkan hasil penelitian Sutardi (2009) penggunaan model inkuiri dapat meningkatkan aktivitas siswa pada materi pengembangan percobaan dengan alat sederhana dengan kategori tinggi sebesar
$63,81 \%$. Sedangkan aktivitas siswa terendah yang diperoleh adalah membaca (membaca buku pegangan atau penunjang dan membaca pertanyaan-pertanyaan dalam LKS) sebesar $77 \%$ dengan kategori aktif. 
Artinya sebagian besar siswa membaca buku yang dijadikan sebagai rujukan atau referensi dan membaca LKS yang diberikan guru. Membaca merupakan salah satu tahapan proses penemuan dalam inkuiri. karena dengan membaca siswa dapat menemukan informasi untuk mencari jawaban atau memecahkan masalah terhadap pertanyaan yang ada. Hal ini ditegaskan oleh Depdikbud (dalam Admin, 2009) bahwa model inkuiri merupakan proses mengevaluasi buku dan sumber-sumber informasi lain secara kritis.

Pemahaman konsep siswa dalam pembelajaran diperoleh dari hasil tes setelah pembelajaran selesai. Secara keseluruhan rata-rata persentase pemahaman konsep siswa sebesar $64,53 \%$ dengan kategori baik. Secara umum siswa sudah cukup mampu menjawab konsep yang diujikan. Nilai tes pemahaman tertinggi diperoleh pada pemahaman konsep soal nomor 4 yaitu menyebutkan tiga bagian dari usus halus sebesar $96,6 \%$ dan pemahaman konsep soal nomor 2 yaitu menyebutkan nama uji makanan yang dilakukan sebesar $89 \%$, dengan kategori sangat baik. Selama pembelajaran pada pertemuan pertama, siswa diarahkan untuk dapat menemukan sendiri tiga bagian dari usus halus melalui tayangan VCD yang diputar. Dalam tampilan VCD siswa dapat melihat dengan jelas bagian dari usus yang dipotong kemudian dibelah sehingga akan tampak bagian-bagian dari usus halus.

Pada konsep soal nomor 2 tentang uji makanan, siswa mampu menjawab dengan baik karena pada proses pembelajaran siswa diarahkan untuk menemukan sendiri bahan makanan yang diuji. Sesuai dengan RPP 2 pada uji makanan siswa di bagi menjadi 6 kelompok dengan masing-masing kelompok terdiri dari 7-8 orang. Masing-masing kelompok mendapat bahan makanan yang berbeda, kelompok 1,2 dan 3 mendapatkan roti, susu, dan tepung terigu. Kelompok 4,5 dan 6 mendapatkan telur, kacang tanah dan kacang kedelai. Setelah mendapatkan bahan makanan yang berbeda, masing-masing kelompok melakukan eksperimen untuk mendapatkan data, sehingga siswa dapat menjawab pertanyaan pada konsep tersebut. LKS 2 berisi pertanyaan yang berkaitan dengan kegiatan yang dilakukan pada tahap ketiga model penerapan inkuiri yaitu mengumpulkan data melalui eksperimen. Hal ini sejalan dengan pendapat Schmidt (dalam Admin, 2009) bahwa inkuiri adalah suatu proses untuk memperoleh dan mendapatkan informasi dengan melakukan observasi atau eksperimen untuk mencari jawaban atau memecahkan masalah terhadap masalah atau rumusan masalah dengan menggunakan kemampuan berfikir kritis dan logis. Nilai tes terendah diperoleh pada butir soal nomor 6 yaitu menyebutkan saluran pencernaan dan kelenjar pencernaan sebesar $18.8 \%$ dengan kategori sangat kurang. Pada butir soal nomor 6 banyak siswa yang keliru dalam mengurutkan saluran pencernaan dan menyebutkan kelenjar pencernaan. Siswa salah dalam menjawab antara saluran pencernaan dan kelenjar pencernaan. Hal ini terjadi karena selama pembelajaran, 
yaitu pada pertemuan pertama tampilan VCD yang ditayangkan hanya menjelaskan proses masuknya makanan dan macam-macam saluran pencernaan dan kelenjar pencernaan secara garis besar saja. Tampilan VCD merupakan salah satu tahapan proses penemuan dalam inkuiri. karena melalui tavangan VCD sistem pencernaan makanan diharapkan siswa dapat menemukan sendiri nama saluran pencernaan dan nama kelenjar pencernaan sesuai dengan apa yang mereka temukan.

Penerapan model inkuiri yang telah dilakukan memberikan efek pada pemahaman konsep siswa dibuktikan dengan menghitung jumlah skor jawaban siswa. Maka dapat disimpulkan bahwa penerapan dengan model inkuiri dapat meningkatkan pemahaman konsep siswa pada pokok bahasan sistem pencernaan makanan di kelas VIII SMPN 1 Sukadana. Pertanyaanpertanyaan yang dibuat dalam pemahaman konsep bersifat pertanyaan efektif dan keterampilan berfikir. Sehingga siswa lebih terarah dan sistematis, dan berimplikasi pada pemahaman konsepnya. Sedangkan pada pemahaman konsep soal nomor 1 yaitu menyebutkan nama kelenjar yang menghasilkan saliva dan fungsinya sebesar $48,5 \%$ tergolong kategori cukup. Nilai tes terendah diperoleh pada butir soal nomor 6 yaitu menyebutkan saluran pencernaan dan kelenjar pencernaan sebesar $18,8 \%$ dengan kategori sangat kurang.

Sebagai data penunjang dilakukan juga perhitungan pada hasil kerja sama siswa dalam mengerjakan LKS. LKS merupakan stimulus atau bimbingan guru yang disajikan secara tertulis dan bertujuan untuk mengaktifkan siswa dalam proses pembelajaran, membantu siswa mengembangkan konsep dan menambah informasi tentang materi yang dipelajari. LKS memungkinkan

pembelajaran yang sistemats meme sistematis untuk menjawaban masalah dengan cara menjawab pertanyaan yang berhubungan dengan model inkuiri dan membuat siswa dapat mengikuti pembelajaran secara aktif dan menyenangkan (Bulu, 1993). Ratarata persentase hasil pengerjaan LKS pada masing-masing kelompok

Tabel 5. Rata-rata Persentase Lembar Kerja Siswa Selama KBM

\begin{tabular}{|c|c|c|c|c|}
\hline \multirow{2}{*}{ No } & \multirow{2}{*}{$\begin{array}{l}\text { Nama Anggota } \\
\text { Kelompok }\end{array}$} & \multirow{2}{*}{\multicolumn{2}{|c|}{ Persentase Hasil LKS(\%) }} & \multirow[b]{2}{*}{$\begin{array}{c}\text { Rata-rata } \\
(\%)\end{array}$} \\
\hline & & Pertemuan I & & \\
\hline 1 & 1 & 81,25 & 100 & 90,62 \\
\hline 2 & 2 & 75 & 100 & 87.5 \\
\hline 3 & 3 & 81,25 & 100 & 90.62 \\
\hline 4 & 4 & 81,25 & 100 & 90.62 \\
\hline 5 & 5 & 81,25 & 83,33 & 82.29 \\
\hline 6 & 6 & 81,25 & 100 & 90,62 \\
\hline \multicolumn{2}{|r|}{ Total } & 481,25 & 583,33 & 532,27 \\
\hline \multicolumn{2}{|r|}{ Rata-rata } & 80,20 & 97,22 & 88,71 \\
\hline
\end{tabular}

Dari data yang telah disajikan di atas, secara keseluruhan rata-rata persentase hasil LKS dari semua kelompok adalah $88,71 \%$ Hal ini menunjukkan bahwa siswa dapat memecahkan masalah berupa 
pertanyaan-pertanyaan dalam LKS. Rata- rata persentase hasil pengerjaan LKS pada masing-masing kelompok. LKS merupakan instrumen pembelajaran yang berfungsi untuk menunjang keaktifan belajar siswa. Secara keseluruhan aktivitas siswa dikatakan aktif atau tinggi dengan rata-rata persentase

\section{Simpulan dan Saran}

Penerapan model inkuiri dapat meningkatkan aktivitas siswa pada pokok bahasan sistem pencernaan makanan di kelas VIII SMPN 1 Sukadana sebesar 85,15 dengan kategori aktif.

Penerapan model inkuiri dapat meningkatkan pemahaman konsep siswa pada pokok bahasan sistem pencernaan makanan di kelas VIII

\section{Daftar Pustaka}

Admin. 2009. Model Pembelajaran Inkuiri. http : //agungprudent Wordpress.com/2009/05/16/track back, diakses 7 Desember 2009.

Alhaddad, SF. 2002. Pembelajaran Matematika Realistik Pokok Bahasan Pecahan di SD Muhammadiyah 4 Surabaya Tesis-Surabaya. Universitas Surabaya : Tidak Diterbitkan.

Anonim. Tanpa tahun. Model inkuiri. (online). (http: //www.siaksoft. net), diakses 4 Januari 2009

- Tanpa tahun. Pemahaman Konsep. (online). (http: //www. ipotes. wordpress.com), diakses 4 Januari 2009.
$85,15 \%$ dan didukung dengan ratarata hasil pengerjaan LKS yang juga tinggi yaitu $90.62 \%$. Hal ini menunjukkan bahwa siswa aktif dalam pembelajaran sistem pencernaan makanan pada manusia dalam menerapkan model inkuiri.

SMPN 1 Sukadana dengan nilai 64,53 dengan kategori baik.

Penerapan model inkuiri dapat menjadi pertimbangan bagi guru biologi untuk dapat digunakan dalam pembelajaran pada pokok bahasan sistem pencernaan makanan karena dapat meningkatkan aktivitas siswa. Perlu dilakukan penelitian lebih lanjut untuk melihat kemampuan pemahaman konsep belajar siswa.

Arikunto, S. 2002. Dasar-dasar Evaluasi Pendidikan. Yogyakarta : Bumi Aksara.

Bulu. 1993. Mendalami dan Menganalisa Materi Pengajaran, Membuat dan Menerapkan LKS. Ujung pandang. (Diklat http : bpgupg.go.id), diakses 15 Desember 2009.

Depdiknas. 2003. Standar Kompetensi Mata pelajaran Biologi Kurikulum 2004. Jakarta : Depdiknas.

Depdiknas. 2006. Panduan Penyusunan KTSP Pendidikan Dasar dan Menengah Kurikulum BALITBANG. Jakarta : Depdiknas. 
Gulo, W. 2002. Strategi Belajar Mengajar. Jakarta : Grasindo.

Purwanto, MN. 1991. Prinsip-prinsip dan tehnik Evaluasi Pengajaran Bandung : Remaja Rosdakarya.

Riduwan. 2002. Skala Pengukuran Variabel-Variabel Penelitian. Bandung: Alfabeta.

Roestiyah. 2001. Strategi Belajar Mengajar. Jakarta : Rineka Cipta.
Sanjaya, W. 2008 Kurikulum dan Pembelajaran. Jakarta : Kencana Prenada Media Group.

Sugiyono. 1997. Metode Penelitian Administrasi. Bandung : Alfabeta

Suzana. 2003. (http : // Jurnal IPI. Wordpress. Com). diakses 1 Januari 2009

Yasa, D. 2008. Aktivitas dan Prestasi Belajar: (http: /ipotes. Wordpress. Com). diakses 24 Mei

2008. 